\title{
Geoquímica e geocronologia de granitóides tipo A da região de Cocalinho, leste do estado de Mato Grosso
}

\author{
Jamil Xavier dos Santos ${ }^{1}$, Rubia Ribeiro Viana ${ }^{2}$, Ana Cláudia Dantas da Costa², \\ Amarildo Salina Ruiz ${ }^{3} \&$ Gislaine Amorés Battilani ${ }^{2}$
}

\begin{abstract}
Resumo Neste trabalho são apresentados resultados preliminares de estudos geoquímicos e geocronológicos de granitos deformados, denominados neste trabalho de Ortognaisse Itacaiu, que afloram na porção leste do Estado de Mato Grosso, a sul do Município de Cocalinho. Os dados geoquímicos de elementos maiores, menores e traços de 09 amostras analisadas, indicaram que essas rochas apresentam um magmatismo evoluído, de composição álcali-granítica, extremamente ácida e diferenciada. Os elevados valores nos conteúdos de $\mathrm{Zr}$ e $\mathrm{K}_{2} \mathrm{O}$ evidenciam que essas rochas têm as mesmas características dos granitos tipo A. Observou-se enriquecimento dos elementos terras raras leves (ETRL) em relação aos terras raras pesados (ETRP) e acentuada anomalia negativa de Eu, sendo esta última feição, indicativa da evolução por fracionamento de plagioclásio. Os dados geocronológicos mostraram valores aproximados de 815 e 667 Ma que podem ser interpretados, respectivamente, como produto de uma herança isotópica e como a idade de cristalização da rocha. Novos dados estão em processo de aquisição para tentar elucidar o posicionamento dessas rochas no contexto regional da área, principalmente em relação ao Arco Magmático de Goiás e a Faixa Paraguai, já que as mesmas estão inseridas entre estas duas unidades.
\end{abstract}

Palavras-chave: Geoquímica, Geocronologia, Ortognaisse Itacaiu, granito tipo A, Cocalinho, MT

\begin{abstract}
Geochemical and Geochronology of the A type granite of the Cocalinho region, east of the Mato Grosso State. In this work are presented the preliminary dates of geochemical and geochronological studies of deformed granite, here named of Itacaiu Orthogneiss, that crop up in the east portion of the Mato Grosso State, the southern of Cocalinho city. None samples were analyzed in terms of major, minor and trace elements. The chemical information indicates evaluated magmatism and alkali-granite composition, extremely differentiated. The high values in the contents of $\mathrm{Zr}$ and $\mathrm{K}_{2} \mathrm{O}$ shows that the protholit of this rocks is a type-A granite. Also is observed that there is an enrichment of the light earth rare elements in relation to hardy earth rare elements with a strong Eu anomaly. The strong Eu anomaly is typical from plagioclase fractionate. The geochronology dates by the U-Pb method show two consistent ages, one in $667 \mathrm{Ma}$, assigned as the crystallization age of rock and another around $815 \mathrm{Ma}$ that could be related to an inheritance isotope, being therefore Neoproterozoic age. New dates to elucidate the questions about the geological context of these rocks and their relationship with those from the Arc magmatic of Goias and Paraguai Belt are being performed, already that rocks are between these two units.
\end{abstract}

Keywords: Geochemical, geochronology, Itacaiu orthogneiss, type-A granite, Cocalinho, MT.

INTRODUÇÃO O arcabouço geológico da área é representado pelas rochas que compõem a Faixa Paraguai e o Arco Magmático de Goiás. A Faixa Paraguai é um cinturão curvilinear situado ao sul do Cráton Amazônico e composto por rochas metassedimentares e metavulcânicas dos Grupos Cuiabá, Alto Paraguai e Formações Puga, Bauxi, Araras e Diamantino (Almeida 1974, Figueiredo \& Olivatti 1974). O Arco Magmático de Goiás, definido por Pimentel \& Funk (1987) deu-se com a subducção de crosta oceânica e o envolvimento de um arco de ilhas imaturo acompanhado de um magmatismo mantélico que gerou corpos sin- a tardi-tec- tônicos (granitóides calci-alcalinos, típicos de regiões orogênicas), além de corpos pós-tectônicos ricos em álcalis e típicos de estágios finais de eventos orogênicos.

Os dados apresentados são referentes aos estudos petrográficos, geoquímicos e geocronológicos de rochas coletadas na porção leste do estado de Mato Grosso a sul do município de Cocalinho, próximo às margens do Rio Araguaia (Fig. 1). Estas rochas são pouco conhecidas e este é o primeiro artigo que aborda o significado tectônico desta unidade nova.

Dados preliminares indicam que as rochas estudadas pertencem à suíte de rochas graníticas do tipo $\mathrm{A}$.

1 - Universidade Federal de Mato Grosso (UFMT), Programa de Pós Graduação em Geociências, Cuiabá (MT), Brasil.

E-mail: jamilsantos.jemil@bol.com.br

2 - Universidade Federal de Mato Grosso (UFMT), Departamento de Recursos Minerais, Cuiabá (MT), Brasil.

E-mail: rubia@cpd.ufmt.br, acdcosta@cpd.ufmt.br, gislainexand@hotmail.com

3 - Universidade Federal de Mato Grosso (UFMT), Departamento de Geologia Geral, Cuiaba (MT), Brasil. E-mail: aruiz@cpd.ufmt.br 


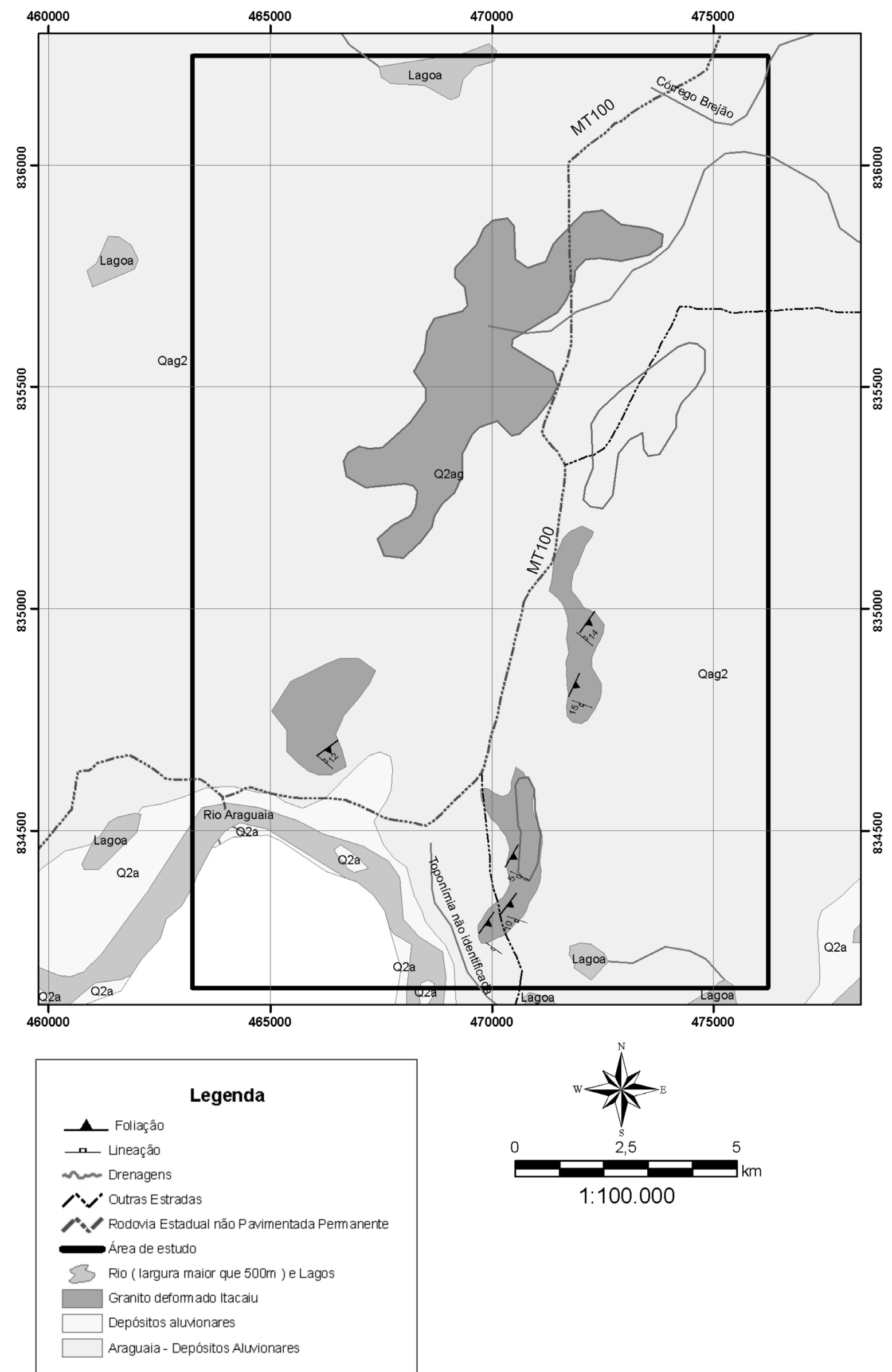

Figura 1 - Esboço geológico da área de estudo entre a Faixa Paraguai e o Maciço de Goiás. 
O termo granito do tipo A foi usado pela primeira vez por Loiselle \& Wones (1979) para caracterizar granitóides anorogênicos, anídricos que ocorrem ao longo de zonas de riftes e no interior de blocos continentais estáveis, ou seja, uma definição que engloba termos de ambiente tectônico e características químicas. Eby (1992) subdividiu granitos tipo A em dois grupos quimicamente distintos, o primeiro denominado de A1 caracterizado por concentrações de elementos similares àquelas observadas em basaltos de ilhas oceânicas, e o segundo grupo, A2, representado por concentrações de elementos químicos que variariam desde aquelas observadas em rochas da crosta continental até basaltos de arcos de ilhas. Para explicar as diferenças químicas observadas nos grupos A1 e A2, Eby (op. cit.) aventa a existência de dois tipos de fonte muito distintos, tanto química quanto tectonicamente. Bonin (2007) faz uma revisão sobre a evolução de granitos tipo $\mathrm{A}$, no qual apresenta várias teorias e discussões apresentadas na literatura sobre o tema e deixa claro que estas rochas são alcalinas, enriquecidas em elementos traços incompatíveis e pobres em elementos traços compatíveis em magmas silicáticos máficos $(\mathrm{Co}, \mathrm{Sc}, \mathrm{Cr}, \mathrm{Ni})$ e feldspatos (Ba, Sr, Eu). Granitos do tipo A são localizados em diferentes localidades, ocorrendo desde a América do Norte até a América do Sul, tanto quanto nos continentes europeu, africano e Oceania e a idade de colocação vai do Arqueano até o recente. Qiu et al. (2005) definem que de acordo com as características químicas e mineralógicas, um granito tipo A pode ser subdividido em dois subgrupos, um aluminoso caracterizado pela presença de minerais ricos em alumínio (espessartita e muscovita rica em $\mathrm{Mn}$ ) e outro peralcalino que contém riebequita, arfvedsonita e aegirina. Ainda segundo esses autores, granitos aluminosos tipo A apresentam menores concentrações de $\mathrm{Nb}, \mathrm{Zr}, \mathrm{Ga}$, elementos terras raras e valores mais baixos das razões $\mathrm{FeO} * \mathrm{MgO}$ and $\mathrm{Ga} / \mathrm{Al}$ que os granitos do subgrupo peralcalino.

O objetivo principal deste trabalho foi a caracterização das rochas de filiação granítica encontradas na área de estudo, além de procurar responder a questões essenciais para a melhor compreensão da geologia local: São estas rochas prolongamento do Arco Magmático de Goiás? São as rochas estudadas o embasamento das rochas da Faixa Paraguai na região? Ou são unidades mais jovens que estão intrudidas nas seqüências da Faixa Paraguai?

ARCABOUÇO GEOLÓGICO A área de estudo está inserida entre duas unidades geotectônicas de grande expressão pertencentes à Província Tocantins, a Faixa Paraguai a oeste e o Arco Magmático de Goiás a leste (Fig. 2).

Os primeiros pesquisadores a sugerirem a existência do Arco Magmático de Goiás, foram Pimentel e Funk (1987), cuja origem, segundo estes autores, deu-se a partir da convergência do Cráton Amazônico e de um possível conjunto de microplacas, representado pelo Maciço de Goiás, durante o Neoproterozóico. A formação deste arco se deu com a subducção de crosta oceânica e o envolvimento de um arco de ilhas imaturo acompanhado de um magmatismo derivado do manto $\left({ }^{87} \mathrm{Sr} /{ }^{86} \mathrm{Sr}<0,710\right)$, gerando corpos sin- a tardi-tectônicos, similares a granitóides calci-alcalinos de regiões orogênicas, além de corpos pós-tectônicos ricos em álcalis típicos de estágios finais de eventos orogênicos. O Arco Magmático de Goiás foi dividido em duas seqüências: o Arco de Mara Rosa, situado a norte da Província Tocantins e o Arco de Arenópolis, situado no centro sul da Província Tocantins.

O Arco de Mara Rosa foi primeiramente considerado como uma seqüência greenstone-belt do Arqueno (Almeida 1984, Schobbenhaus et al. 1984), entretanto Ribeiro Filho (1981) definiu-o como uma seqüência do neoproterozóico e demonstrou a ocorrência de uma discordância entre o Arco de Mara Rosa e a faixa Arqueana de Pilar e correlacionou-o com as seqüências vulcanosedimentares de Palmeirópolis, Indianópolis e Juscelândia, pertencentes ao Neoproterozóico. Kuyumjian (1994) destacou que a seqüência Mara Rosa sofreu um processo de cavalgamento por meio da falha de empurrão Rio dos Bois, sobrepondo-a aos terrenos granito-greenstone de Pilar de Goiás-Hidrolina, corroborando com a sugestão de Ribeiro Filho (1981). Pimentel et al. (1993) datou os gnaisses tonalíticos dessa unidade e as rochas metavulcânicas pelo método $\mathrm{U}-\mathrm{Pb}$, cujos resultados foram de 856 $\pm 13 \mathrm{Ma}$ e $862 \pm 8 \mathrm{Ma}$, respectivamente, evidenciando a idade neoproterozóica para esta seqüência. O metamorfismo da fáceis xisto verde alto a anfibolito desta seqüência tem idade de $632 \pm 4 \mathrm{Ma}$.

Viana et al. (1995), propõem cinco grupos distintos para as unidades litológicas de Mara Rosa: ortognaisses, rochas metavulcânicas máficas, rochas metassedimentares, granitos deformados e corpos intrusivos de composição gabróica e granítica. Portanto, essas interpretações a respeito das rochas que ocorrem na região de Mara Rosa modificaram o papel que elas exerciam de um ambiente greenstone para um ambiente de arco de ilhas. As unidades vulcanossedimentar, gnáissica e os corpos intrusivos, que antes eram interpretadas separadamente, passaram a ser considerados como uma continuidade dentro do processo evolutivo de um ambiente de arco de ilhas.

$\mathrm{O}$ arco de Arenópolis é formado essencialmente por ortognaisses e seqüências vulcano-sedimentares do Neoproterozóico e granitóides pós-orogênicos do Paleozóico Inferior, que intrudem a crosta juvenil neoproterozóica (Pimentel \& Fuck 1992, Rodrigues 1996, Gioia et al. 1997). Os ortognaisses apresentam granulação média, com presença de hornblenda e biotita na sua composição mineralógica, que varia de tonalítica a granítica. Os conteúdos de elementos traços destes ortognaisses apresentam feições típicas de granitóides calci-alcalinos. Os dados U-Pb e Rb-Sr mostram idades entre 900 e 640 Ma para a cristalização e 632 Ma para o último evento tectono- metamórfico a que foram submetidas essas rochas.

A Faixa Paraguai é um cinturão curvilinear com mais de 1500 km, situada ao sul do Cráton Amazônico, circundando a borda SE desse craton, é composta por rochas metassedimentares dos grupos Cuiabá, Alto Paraguai e formações Puga, Bauxi, Araras e Diamantino 


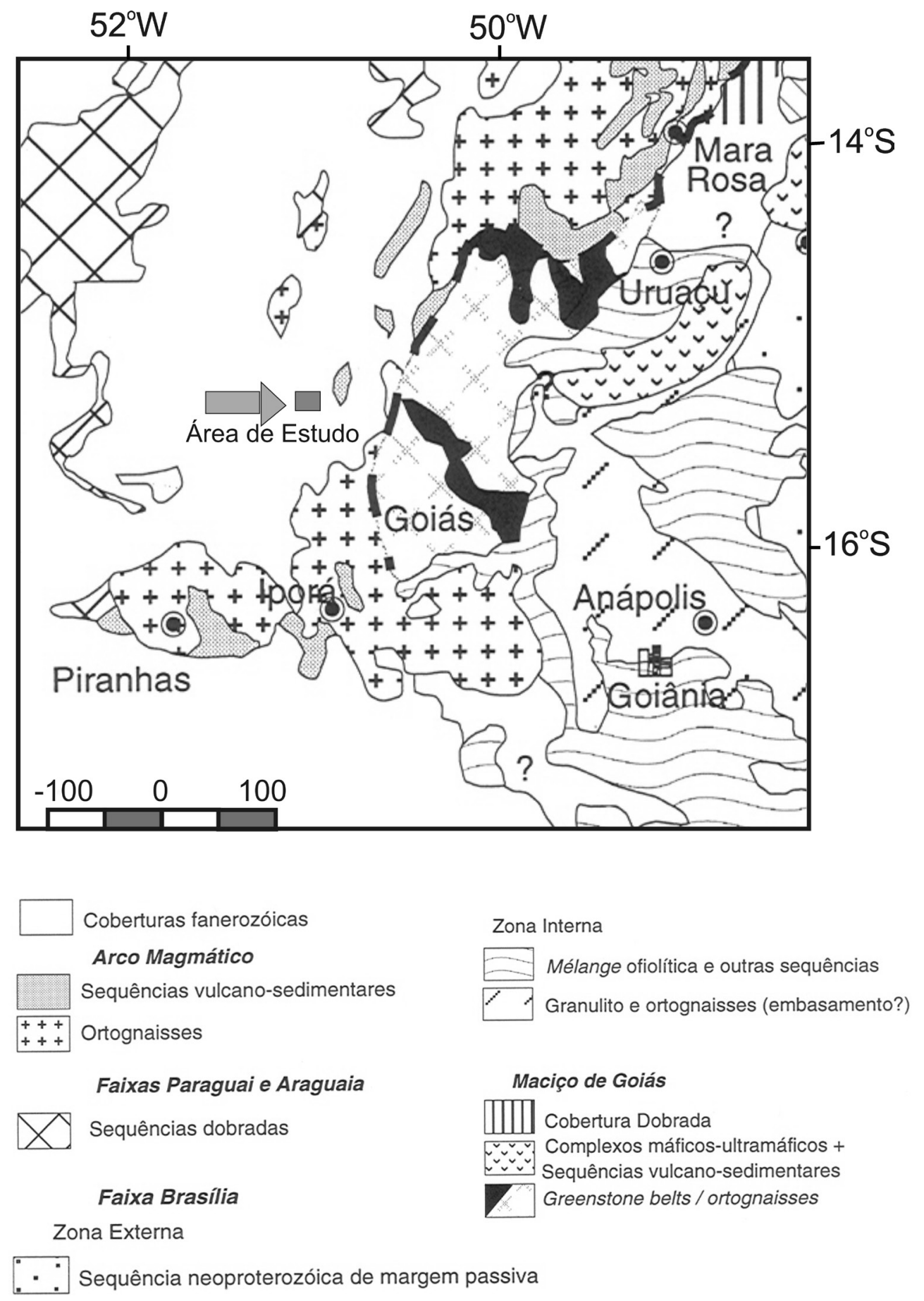

Figura 02 - Mapa Geológico da Província Tocantins e localização da área de estudo. Modificado de Fuck et al. 1994.

(Almeida 1974, Figueiredo \& Olivatti 1974).

Pinho (1990) subdividiu o Grupo Cuiabá, individualizando uma seqüência meta-vulcanossedimentar, que denominou de Nova Xavantina e que foi renomeada por Martinelli \& Batista (2003) como Seqüência Araés, que definiram da base para o topo três associações: 1) Meta-Vulcânica, com meta-basalto e meta-tufo na base, seguida por xistos, meta-andesito e lapili-tufo; 2) Química, com formações ferríferas bandadas, filitos carbonáticos e metacherts; 3) Clástica, com meta-silti- tos, meta-argilitos e quartzitos.

A Faixa Paraguai foi subdividida por Lacerda Filho et al. (2001) em dois domínios principais, um de Margem Passiva, apresentando rochas remanescentes de crosta oceânica e o outro domínio correspondente a uma seqüência típica de Bacia de Ante-País. Segundo esses autores, o domínio de Margem Passiva é marcado por uma seqüência de rochas sedimentares, na qual, a base apresenta sedimentos químicos e camadas de filitos carbonosos, indicando ambiente redutor profundo, 
sugerindo uma posição de talude e distal da margem da plataforma. Esse domínio corresponde ao Grupo Cuiabá. O domínio de Bacia de Ante-País é representado por uma seqüência siliciclástica, na base, que encobre a plataforma carbonática. As rochas desta seqüência foram associadas ao Grupo Alto Paraguai e são constituídas predominantemente por arenitos com estratificação cruzada e arcósios finos a grosseiros (correspondente a Formação Raizama) e por folhelhos vermelhos, siltitos e arcósios, correspondentes a Formação Diamantino. Datação radiométrica $\mathrm{Rb}-\mathrm{Sr}$ das rochas deste domínio forneceram idade de $568+20$ Ma que foi interpretada como a idade da diagênese (Bonhomme et al. 1982).

Segundo Pinho et al. (2003), as rochas da Faixa Paraguai sofreram deformação entre 500-560 Ma (Orogênese Brasiliana) e foram afetadas por magmatismo granítico pós orogenético (Suíte São Vicente) de idade $504 \pm 5$ Ma. Alvarenga \& Trompette (1993), usando os índices de cristalinidade da illita determinaram a evolução metamórfica, identificando quatro episódios sucessivos de deformação progressiva para a faixa, sendo que as três primeiras fases são quase co-axiais com direção NE-SW e o quarto episódio apresenta direção NW-SE.

Sousa (1997) descreve uma associação de rochas de caráter dominantemente alcalino, denominado de Complexo Ponta do Morro, que são rochas de composição granítica e sienítica levemente supersaturada e classificadas no diagrama QAP, como álcali-feldspato granito, quartzo álcali-feldspato sienito, álcali-feldspato sienito, quartzo sienito e sienito; correspondentes aos granitos peralcalinos e às séries alcalina sódica e alumino-potássica. Esta associação de rochas apresentam características de ambientes intra-placas segundo classificação proposta por Bowden et al. (1984). Os estudos petrográficos e geoquímicos evidenciaram que o Complexo Ponta do Morro é constituído por uma típica associação de granitóides alcalinos, anorogênicos do tipo A.

MATERIAIS E MÉTODOS Para o desenvolvimento deste trabalho foram realizadas atividades de campo que envolveram mapeamento e coleta de amostras, estudos petrográficos e geoquímicos de 9 amostras previamente selecionadas e estudos geocronológicos. As análises geoquímicas foram desenvolvidas no Laboratório ACMELAB pelo método de fluorescência de Raios-X (WDS) para elementos maiores e por ICP-MS para elementos traços e terras raras. As análises geocronológicas foram realizadas em um aparelho modelo Thermo-Finnigan Neptune pelo método MC-ICP-MS (Lasers Ablation (Multi-collector inductively coupled plasma mass spectrometry) acoplado com um sistema laser NewWave de 213 nm: para obtenção de isótopos $\mathrm{U}-\mathrm{Pb}$ em cristais de zircão.

\section{PETROGRAFIA E METAMORFISMO DO} ORTOGNAISSE ITACAIU Os estudos de campo permitiram identificar pequenos afloramentos de corpos graníticos que ocorrem na forma de lajeados ou blocos soltos em meio a uma área pediplanizada, o que impede que se definam as relações de contato dessas rochas com outras seqüências que ocorrem na área.

As rochas estudadas são corpos deformados, foliados a isotrópicos, apresentam cor cinza escuro a cinza claro, sendo que a cor é dependente da quantidade de minerais máficos (principalmente, biotita) presentes na rocha. A textura quando preservada é, predominantemente, porfirítica inequigranular de granulometria média a grossa, embora em poucos locais tenha sido identificada textura equigranular de granulometria média. Estas rochas apresentam foliação ao longo da qual ocorre uma lineação de estiramento mineral.

A principal feição estrutural observada em campo é uma foliação bem marcada que varia de baixo a alto ângulo com mergulho para sudeste, com atitudes em torno de 140/20 a 120/70 e contido nesta foliação observou-se também lineações de estiramento mineral, cujas atitudes variam entre 185/10 a 203/11. Essas feições estruturais quando comparadas com as rochas do Grupo Cuiabá, na porção nordeste e noroeste de Cocalinho, apresentam o mesmo padrão de foliação, o que permite inferir que essas duas unidades foram afetadas por um mesmo evento deformacional, provavelmente em uma segunda fase de metamorfismo do Arco Magmático de Goiás entre 610-600 Ma, o que, segundo Junges et al. 2002, marca o fechamento da bacia oceânica existente entre os crátons Amazônico e São Francisco. Ao se comparar os valores de atitudes que representam a lineação de estiramento mineral com os da foliação dos Ortognaisses Itacaiu foi possível definir que o movimento que gerou essa deformação foi um movimento obliquo.

Os estudos microscópicos permitiram identificar como principais minerais constituintes feldspato alcalino (microclina), plagioclásio (oligoclásio) (Fig. 3), quartzo e biotita, enquanto que piroxênio sódico (aegerina), anfibólio (riebekita) e zircão são os principais minerais acessórios. A percentagem de quartzo varia de 25 a $30 \%$ da rocha, sendo que a maioria dos cristais mostra-se recristalizados, com extinção ondulante e alguns cristais estão fraturados e estirados, o tamanho dos grãos varia de $0.25 \mathrm{~mm}$ á $1.66 \mathrm{~mm}$. O feldspato alcalino é do tipo microclina (Fig. 3) e a porcentagem deste mineral varia de 40 a $60 \%$, alguns grãos exibem intercrescimento pertítico e mesopertítico (Fig. 3). A percentagem de oligoclasio varia de 10 a $15 \%$. A biotita (2 a $8 \%$ ) é intersticial, apresenta hábitus tabular e algumas palhetas estão deformadas. Os piroxênios (aegirina), anfibólios (riebekita) (Fig. 3), opacos, zircão, titanita, representam a assembléia de minerais acessórios, enquanto que sericita, minerais do grupo do epidoto (epidoto, zoizita e clinozoisita) e clorita são produto de alteração do feldspato e da biotita.

\section{RESULTADOS E DISCUSSÕES}

Estudos Geoquímicos Na tabela 1 são apresentados os resultados das análises geoquímicas para elementos maiores, menores e traços de nove amostras de ortognaisses.

As análises são caracterizadas por variação moderada na composição em peso de $\mathrm{SiO}_{2} \mathrm{e} \mathrm{Fe}_{2} \mathrm{O}_{3 \text { (total) }}$, cuja concentração média, no caso do primeiro, ou seja, do 

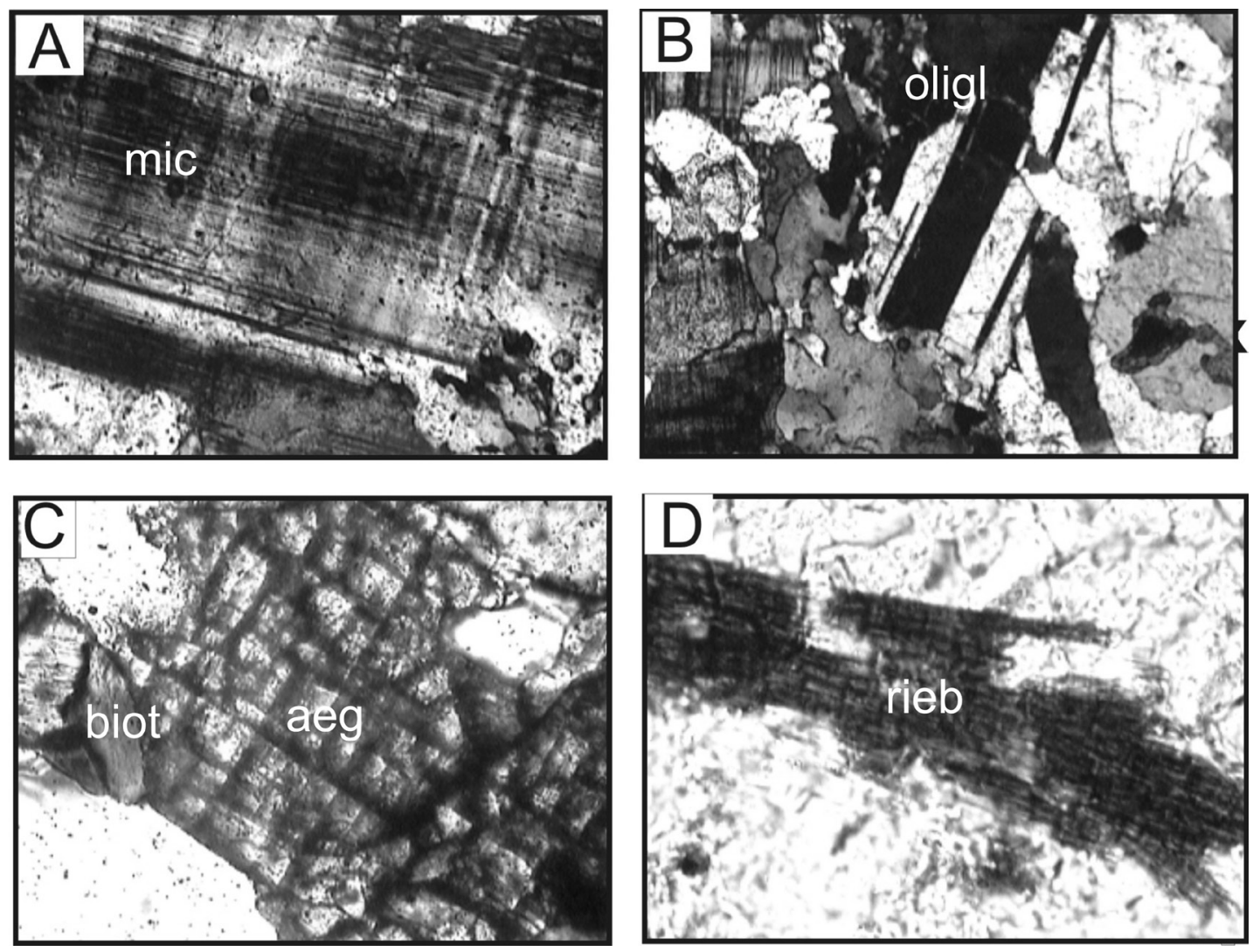

Figura 3 - Fotomicrografias de: (A) Feldspato Alcalino do tipo microclina; (B) Plagioclásio do tipo oligoclásio; (C) Piroxênio (aegirina) de cor verde mostrando uma clivagem perfeita de 90 graus, associada a cristais de biotita; (D) Anfibólio do tipo riebeckita com cor azul característica.

$\mathrm{SiO}_{2}$ é de $77 \%$, sendo o mínimo de 72,64 e máxima de $78,34 \%$ (Tab. 1), que correspondem às amostras I-4 e I-9A, respectivamente, enquanto a soma de álcalis variam de 8,27 a $8,9 \%$. Os demais óxidos, incluindo os álcalis, apresentam pequena variação em suas concentrações, assim como a perda ao fogo, exceto para uma das amostras que apresenta uma baixa concentração de $\mathrm{SiO}_{2}$ quando comparadas com as demais. A alta saturação em sílica reflete um magma de natureza evoluída com composição granítica extremamente ácida e diferenciada.

A composição dessas rochas gnáissicas, em relação a concentração dos elementos maiores e menores, mostrado na tabela 1 e figura $4(\mathrm{R} 1=4 \mathrm{Si}-11(\mathrm{Na}+\mathrm{K})-$ $2(\mathrm{Fe}+\mathrm{Ti})$ e $\mathrm{R} 2=6 \mathrm{Ca}+2 \mathrm{Mg}+\mathrm{Al}$ ) reflete os aspectos petrogenéticos desses gnaisses, que imprimem a eles uma assinatura de granito tipo A e de composição de um álcali granito. Essa composição, também é observada pelas baixas concentrações de $\mathrm{CaO}$ e $\mathrm{MgO}$ e altas concentrações de álcalis e razões $\mathrm{TiO}_{2} / \mathrm{MgO}$ de acordo com dados de literatura (Collins et al. 1982, Wallens et al. 1987, Anderson \& Bender 1989, Eby 1992, Patino Douce 1997, Bonin 2007).

No caso dos elementos traços, exceto a composição do $\mathrm{Rb}, \mathrm{Ga}$, Hf e Sn que exibem pequena variação, os demais, especialmente $\mathrm{Sr}, \mathrm{Y}, \mathrm{Ba}, \mathrm{Zr}, \mathrm{Zn}, \mathrm{Cr}, \mathrm{W}$ e Au mostram uma ampla variação entre as amostras (Tab. 1). O protólito de granitos tipo-A para essas rochas, também é confirmado pela razão $10000 \times \mathrm{Ga} / \mathrm{Al}>2,6$ (Whalen et al. 1987).

Utilizando a sílica como índice de diferenciação, em diagramas de variação binários Harker (Fig. 4), pode-se observar o comportamento dos elementos maiores na evolução magmática dessas rochas. A correlação entre $\mathrm{SiO}_{2}$ versus $\mathrm{Al}_{2} \mathrm{O}_{3}$ não é muito clara e parece ter duas tendências. As melhores tendências negativas estão evidenciadas entre $\mathrm{SiO}_{2} \mathrm{e} \mathrm{TiO}_{2}, \mathrm{CaO}, \mathrm{Fe}_{2} \mathrm{O}_{3}$, $\mathrm{MnO}, \mathrm{MgO}$, (Fig. 4). Os diagramas que correlacionam $\mathrm{P}_{2} \mathrm{O}_{5}$ e $\mathrm{Na}_{2} \mathrm{O}$ (Fig. 4), não evidenciam um padrão de evolução bem definido, observando um relativo paralelismo entre os pontos que as representam, resultante da maior mobilidade apresentada por estes elementos durante a atuação de processos pós-magmáticos. O único elemento que apresenta uma correlação positiva com a sílica é o $\mathrm{K}_{2} \mathrm{O}$ o que corrobora a hipótese de uma cristalização mais tardia de biotita e k-feldspato (Fig. 5), que pode estar relacionada com a grande quantidade de k-feldspato nas rochas. A correlação negativa entre conteúdos de $\mathrm{CaO}, \mathrm{F}_{2} \mathrm{O}_{3}, \mathrm{MnO}, \mathrm{MgO}, \mathrm{TiO}_{2}$ e $\mathrm{P}_{2} \mathrm{O}_{5}$, quando se contrasta com a concentração de $\mathrm{SiO}_{2}$ pode estar relacionado à redução de minerais como plagio- 
Tabela 1 - Resultados das análises químicas para elementos maiores (\% peso) e elementos menores (ppm) dos ortognaisses Itacaiu.

\begin{tabular}{|c|c|c|c|c|c|c|c|c|c|}
\hline (\% peso) & I5A & I5B & I7B & I8A & I9A & I4 & I5 & I8 & 19 \\
\hline $\mathrm{SiO}_{2}$ & 77,45 & 77,79 & 77,58 & 77,18 & 78,34 & 72,64 & 75,84 & 75,19 & 76,3 \\
\hline $\mathrm{TiO}_{2}$ & 0,14 & 0,13 & 0,12 & 0,14 & 0,13 & 0,45 & 0,11 & 0,16 & 0,12 \\
\hline $\mathrm{Al}_{2} \mathrm{O}_{3}$ & 11,17 & 11,09 & 11,52 & 11,6 & 11 & 11,34 & 11,12 & 11,12 & 11,02 \\
\hline $\mathrm{Fe}_{2} \mathrm{O}_{3}$ & 2 & 1,79 & 1,78 & 1,72 & 1,68 & 6,29 & 4,46 & 4,6 & 4,31 \\
\hline MgO & 0,01 & 0,01 & 0,01 & 0,02 & 0,01 & 0,17 & 0,01 & 0,03 & 0,01 \\
\hline $\mathrm{CaO}$ & 0,22 & 0,23 & 0,09 & 0,21 & 0,11 & 0,66 & 0,14 & 0,23 & 0,16 \\
\hline $\mathrm{Na}_{2} \mathrm{O}$ & 3,82 & 3,87 & 3,62 & 3,86 & 3,6 & 3,72 & 3,67 & 3,86 & 3,72 \\
\hline $\mathrm{K}_{2} \mathrm{O}$ & 4,63 & 4,53 & 4,7 & 4,83 & 4,56 & 4,49 & 4,67 & 4,55 & 4,52 \\
\hline $\mathbf{P}_{2} \mathbf{O}_{5}$ & 0,01 & 0,01 & 0,03 & 0,03 & 0,01 & 0,08 & 0,03 & 0,02 & 0,03 \\
\hline MnO & 0,03 & 0,03 & 0,04 & 0,03 & 0,03 & 0,09 & 0,04 & 0,05 & 0,05 \\
\hline LOI & 0,2 & 0,4 & 0,3 & 0,3 & 0,3 & 0,3 & 0,3 & 0,1 & 0,4 \\
\hline $\begin{array}{l}\text { Total } \\
\text { (ppm) }\end{array}$ & 99,68 & 99,68 & 99,9 & 99,91 & 99,77 & 99,63 & 99,79 & 99,91 & 99,83 \\
\hline $\mathbf{B a}$ & 142 & 148 & 189 & 179 & 148 & 269 & 122 & 208 & 141 \\
\hline $\mathbf{R b}$ & 113 & 110 & 88 & 112 & 108 & 139 & 107 & 102 & 103 \\
\hline $\mathbf{S r}$ & 7 & 6 & 12 & 7 & 4 & 30 & 5 & 7 & 3 \\
\hline Y & 213 & 205 & 162 & 182 & 167 & 338 & 109 & 239 & 126 \\
\hline $\mathrm{Zr}$ & 973 & 660 & 475 & 516 & 563 & 1142 & 551 & 532 & 388 \\
\hline Nb & 73 & 43 & 31 & 35 & 37 & 58 & 39 & 36 & 25 \\
\hline Th & 15 & 8 & 6 & 7 & 8 & 19 & 8 & 8 & 6 \\
\hline $\mathbf{P b}$ & 17 & 17 & 13 & 23 & 8 & 22 & 11 & 16 & 12 \\
\hline Ga & 26 & 26 & 25 & 27 & 25 & 31 & 26 & 24 & 26 \\
\hline $\mathbf{Z n}$ & 171 & 164 & 101 & 81 & 39 & 144 & 123 & 83 & 64 \\
\hline $\mathrm{Cu}$ & 1 & 3 & 1 & 3 & 2 & 4 & 3 & 4 & 11 \\
\hline $\mathbf{N i}$ & 7 & 10 & nd & nd & 10 & nd & nd & nd & 8 \\
\hline $\mathrm{Cr}$ & 479 & 445 & 411 & 479 & 445 & 3 & 3 & 3 & 3 \\
\hline Hf & 40 & 23 & 18 & 20 & 19 & 27 & 18 & 17 & 12 \\
\hline Cs & 2 & 2 & nd & 1 & 1 & 2 & 1 & 1 & 1 \\
\hline Sc & nd & nd & nd & nd & nd & 4 & nd & nd & nd \\
\hline Тa & 4 & 3 & 2 & 3 & 3 & 3 & 2 & 2 & 1 \\
\hline Co & 99 & 94 & 78 & 69 & 60 & 92 & 58 & 46 & 39 \\
\hline $\mathrm{Be}$ & 5 & 4 & 5 & 4 & 2 & 6 & 4 & 4 & 4 \\
\hline $\mathbf{U}$ & 5 & 3 & 2 & 3 & 2 & 5 & 3 & 3 & 2 \\
\hline W & 641 & 573 & 516 & 479 & 384 & 719 & 440 & 321 & 282 \\
\hline Sn & 11 & 10 & 6 & 9 & 7 & 12 & 7 & 9 & 6 \\
\hline Au & 5 & 4 & 5 & 2 & 3 & 4 & 25 & 25 & 24 \\
\hline$(\mathrm{Na}+\mathrm{K}) / \mathrm{Al}$ & 2,1 & 2,1 & 2,0 & 2,1 & 2,0 & 2,0 & 2,0 & 2,1 & 2,0 \\
\hline $\mathrm{Al} /(\mathrm{Na}+\mathrm{K}+\mathrm{ca})$ & 0,85 & 0,84 & 0,91 & 0,86 & 0,88 & 0,81 & 0,87 & 0,84 & 0,87 \\
\hline $\mathrm{Al} /(\mathrm{Na}+\mathrm{K})$ & 0,89 & 0,89 & 0,93 & 0,89 & 0,90 & 0,93 & 0,89 & 0,89 & 0,90 \\
\hline $\mathrm{Fe} / \mathrm{Mg}$ & 116 & 104 & 104 & 50 & 98 & 22 & 259 & 89 & 251 \\
\hline $\mathrm{Ti} / \mathrm{Mg}$ & 14 & 13 & 12 & 7 & 13 & 3 & 11 & 5 & 12 \\
\hline $10000 \times \mathrm{Ga} / \mathrm{Al}$ & 8,7 & 9,0 & 8,3 & 8,9 & 8,6 & 10,3 & 8,9 & 8,2 & 8,8 \\
\hline $\mathrm{Y} / \mathrm{Nb}$ & 3 & 5 & 5 & 5 & 4 & 6 & 3 & 7 & 5 \\
\hline $\mathrm{Rb}+\mathrm{Th}+\mathrm{U}+\mathrm{Ta}$ & 137,2 & 124,2 & 98,5 & 124 & 121 & 166,3 & 119,7 & 115,1 & 111,8 \\
\hline $\mathrm{Zr}+\mathrm{Y}+\mathrm{Ce}+\mathrm{Sm}+\mathrm{Yb}$ & 1397 & 1095 & 777 & 863 & 903 & 1927 & 811 & 1081 & 604,4 \\
\hline
\end{tabular}




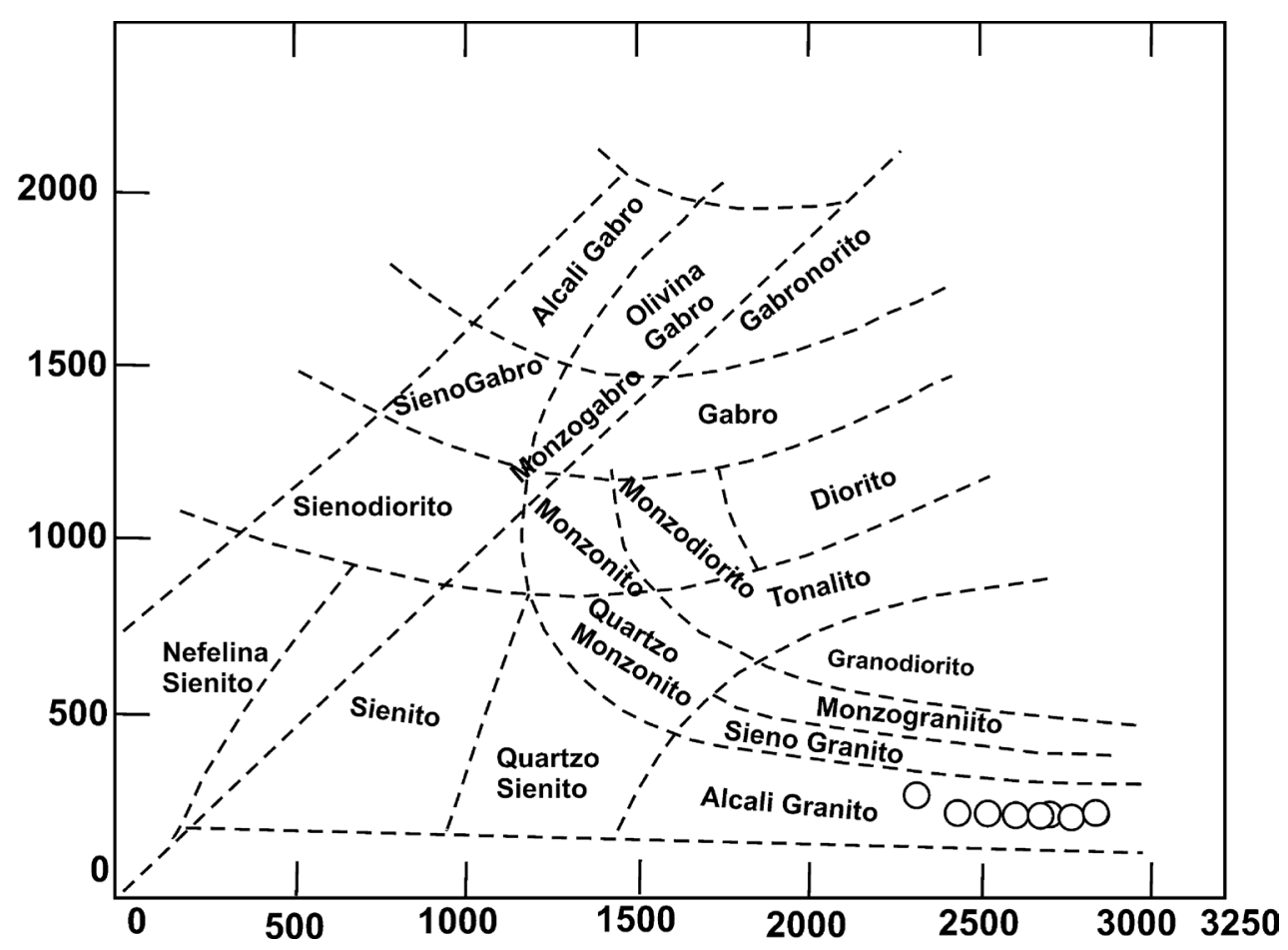

Figura 4 - Diagrama de classificação petrográfica de rochas plutônicas no qual estão plotados os dados das análises geoquímicas das amostras estudadas, calculado a partir das proporções catiônicas $R 1=4 \mathrm{Si}-11(\mathrm{Na}+\mathrm{K})-2-$ $(\mathrm{Fe}+\mathrm{Ti})$ e R2 $=6 \mathrm{Ca}+2 \mathrm{Mg}+\mathrm{Al}$. (Modificado de de la Roche et al., 1980).

clásio cálcico e minerais máficos, tais como biotita, ilmenita, magnetita, titanita e apatita.

A análise dos elementos terras raras por serem menos móveis, mostra maior confiança na interpretação petrogenética, quando comparados às dos elementos maiores. Nas amostras estudadas, os elementos terras raras, cujas concentrações estão expressas na tabela 2 evidencia um maior enriquecimento nos elementos terras raras leves (ETRL), sobre pesados (ETRP). Os diagramas da figura 3, normalizados para condritos, corrobora melhor um único padrão REE, caracterizado pelo enriquecimento ETRL em relação aos ETRP, e evidencia também uma acentuada anomalia negativa de Eu (Fig. 6). Todas as amostras seguem o mesmo padrão, exceto a amostra I4 (aquela de menor concentração em $\mathrm{SiO}_{2}$ ), que mostra uma deficiência em $\mathrm{Ce}$. A forte anomalia negativa de Eu é um indício da evolução por fracionamento do plagioclásio e também é mais uma evidencia de que o protólito das rochas é um granito tipo-A.

$\mathrm{O}$ caráter peralcalino está demonstrado nessas rochas através da relação $(\mathrm{Na}+\mathrm{K}) / \mathrm{Al}$ que é maior que 2 (Giret et al. 1980, Whalen et al. 1987) e através do diagrama de Maniar \& Piccoli (1989), que considera as proporções moleculares $\left(\mathrm{Al}_{2} \mathrm{O}_{3} / \mathrm{CaO}+\mathrm{Na}_{2} \mathrm{O}+\mathrm{K}_{2} \mathrm{O}\right) \mathrm{x}$ $\left(\mathrm{Al}_{2} \mathrm{O}_{3} / \mathrm{Na}_{2} \mathrm{O}+\mathrm{K}_{2} \mathrm{O}\right)$, mostrado na figura 7 . O caráter peralcalino, pode ter relação com a presença de feldspato potássico, mesopertita, e também da alta concentração de zircônio que é típico de rochas peralcalina.

Granitos tipo-A normalmente são formados em ambiente extensional, que é o caso das rochas estuda-
Tabela 2 - Composição dos Elementos Terras Raras, expressos em ppm, para as amostras estudadas.

\begin{tabular}{lccccccccc}
\hline $\begin{array}{l}\text { Elemento } \\
(\mathrm{ppm})\end{array}$ & $\mathrm{I} 4$ & $\mathrm{I} 5$ & $\mathrm{I} 5 \mathrm{~A}$ & $\mathrm{I} 5 \mathrm{~B}$ & $\mathrm{I} 7 \mathrm{~B}$ & $\mathrm{I} 8$ & $\mathrm{I} 8 \mathrm{~A}$ & $\mathrm{I} 9$ & I9A \\
\hline $\mathrm{La}$ & 199.5 & 48.5 & 74.4 & 82.2 & 44.6 & 160.7 & 49.0 & 27.4 & 55.0 \\
$\mathrm{Ce}$ & 369.3 & 125.3 & 168 & 184.5 & 109.5 & 244.6 & 127.4 & 68.4 & 137 \\
$\mathrm{Pr}$ & 53.26 & 15.79 & 22.74 & 25.49 & 15.53 & 51.78 & 16.78 & 9.92 & 19.57 \\
$\mathrm{Nd}$ & 220.5 & 65.7 & 91.5 & 112.3 & 67.1 & 209.6 & 75.7 & 40.7 & 81.4 \\
$\mathrm{Sm}$ & 46.71 & 14.96 & 22.81 & 28.29 & 17.03 & 47.95 & 21.5 & 11.08 & 21.71 \\
$\mathrm{Eu}$ & 4.01 & 1.16 & 1.81 & 2.59 & 1.33 & 3.74 & 2.02 & 0.92 & 1.80 \\
$\mathrm{Gd}$ & 50.58 & 14.83 & 27.11 & 35.87 & 20.10 & 43.07 & 28.23 & 14.05 & 25.03 \\
$\mathrm{~Tb}$ & 9.87 & 2.94 & 5.71 & 6.94 & 4.15 & 7.72 & 5.76 & 3.01 & 5.06 \\
$\mathrm{Dy}$ & 53.53 & 16.92 & 31.50 & 36.46 & 24.02 & 37.46 & 31.80 & 17.78 & 28.13 \\
$\mathrm{Ho}$ & 10.04 & 3.23 & 6.51 & 6.90 & 4.91 & 6.41 & 6.16 & 3.58 & 5.42 \\
$\mathrm{Er}$ & 30.67 & 10.65 & 20.07 & 19.25 & 14.67 & 19.21 & 17.61 & 11.02 & 15.78 \\
$\mathrm{Tm}$ & 4.47 & 1.67 & 3.24 & 2.95 & 2.32 & 2.64 & 2.68 & 1.61 & 2.46 \\
$\mathrm{Yb}$ & 30.83 & 11.16 & 20.30 & 17.70 & 13.89 & 17.47 & 16.10 & 10.94 & 14.78 \\
$\mathrm{Lu}$ & 4.21 & 1.56 & 2.96 & 2.50 & 2.06 & 2.47 & 2.29 & 1.51 & 23.19 \\
\hline
\end{tabular}

das, e freqüentemente ocorrem em ambiente anorogênico (Barbarin 1999) ou em ambiente pós-orogênico, 


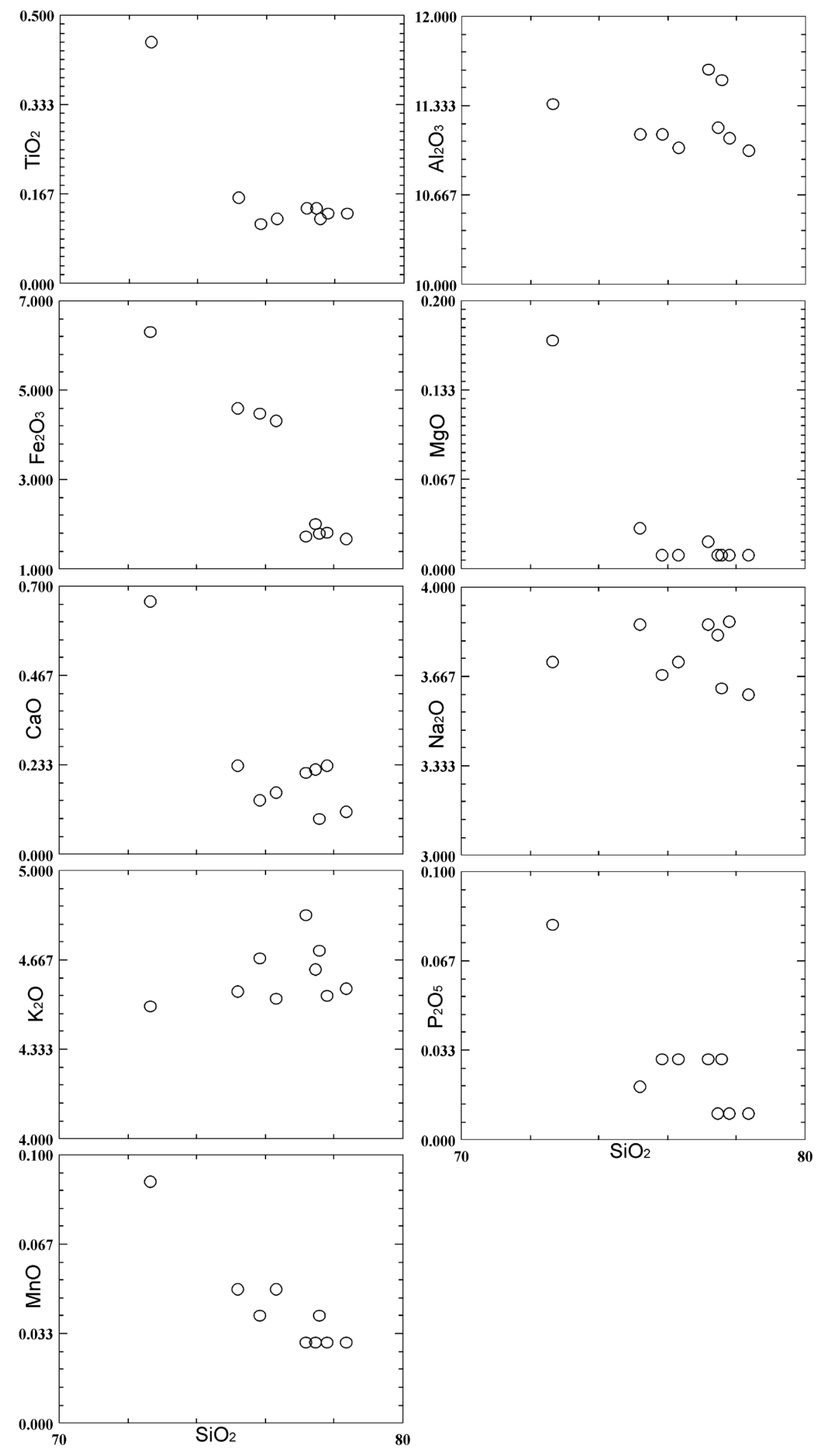

Figura 5 - Diagramas Harker para ortognaisses Itacaiú, utilizando $\mathrm{SiO}_{2}$ como diferenciador.

no intervalo de 10 a 20 Ma depois de cessada a última orogênese (subducção ou colisão continente-continente) (Eby 1992). A investigação do ambiente geotectô- nico, feita a partir de diagramas de Pearce et al. (1984) que utilizam os elementos traços, $\mathrm{Rb} \times(\mathrm{Y}+\mathrm{Nb})$ e $\mathrm{Nb}$ x Y, como discriminantes (Fig. 8) mostra resultados para 

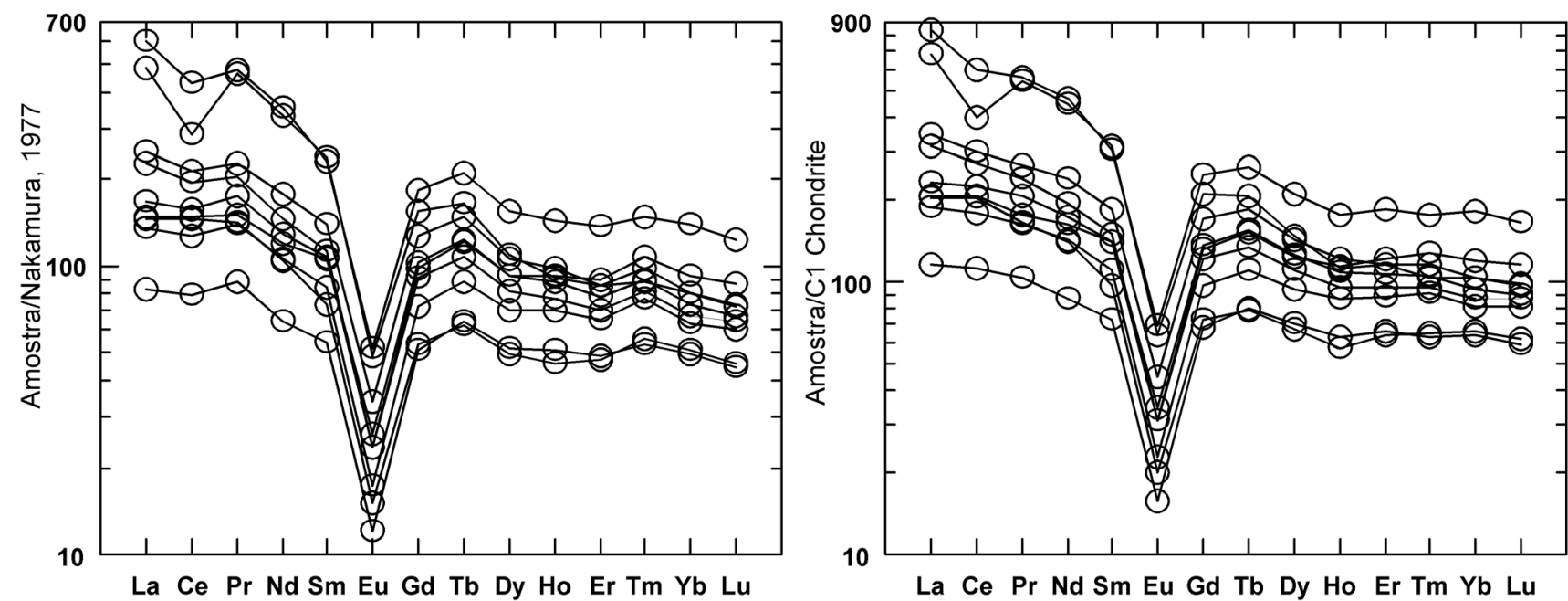

Figura 6 - Distribuição dos elementos terras raras dos ortognaisse Itacaiú, normalizada para dados de: (A) Nakamura 1977 e (B) condrito.

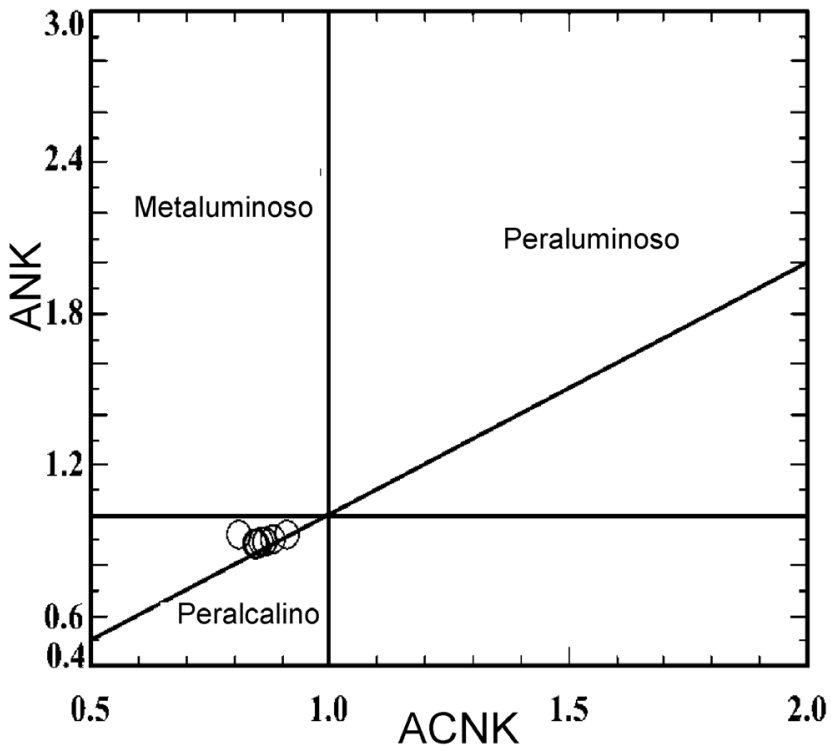

Figura 7 - Diagrama de saturação de alumínio, segundo critérios de classificação proposto por Maniar \& Piccoli (1989), para as rochas estudadas.

granitóides intraplaca (intervalo WPG do gráfico). Eby (1992) verificou que a razão Y/Nb é relativamente constante em cada tipo de granito e, assim, poderia ser usado para discriminar ambientes tectônicos, classificando granitos tipo-A em dois subtipos, aqueles cuja relação $\mathrm{Y} / \mathrm{Nb}<1.2$ como sendo intraplaca e aqueles, cuja razão $\mathrm{Y} / \mathrm{Nb}>1.2$, denominados de pós-colisional (Fig. 9). Para as rochas estudadas, conforme observado na tabela 3, a razão $\mathrm{Y} / \mathrm{Nb}$ varia de 2 a 7 , permitindo classificar estas rochas como granitos tipo-A pós-colisionais.

ESTUDOS GEOCRONOLÓGICOS Dezoito
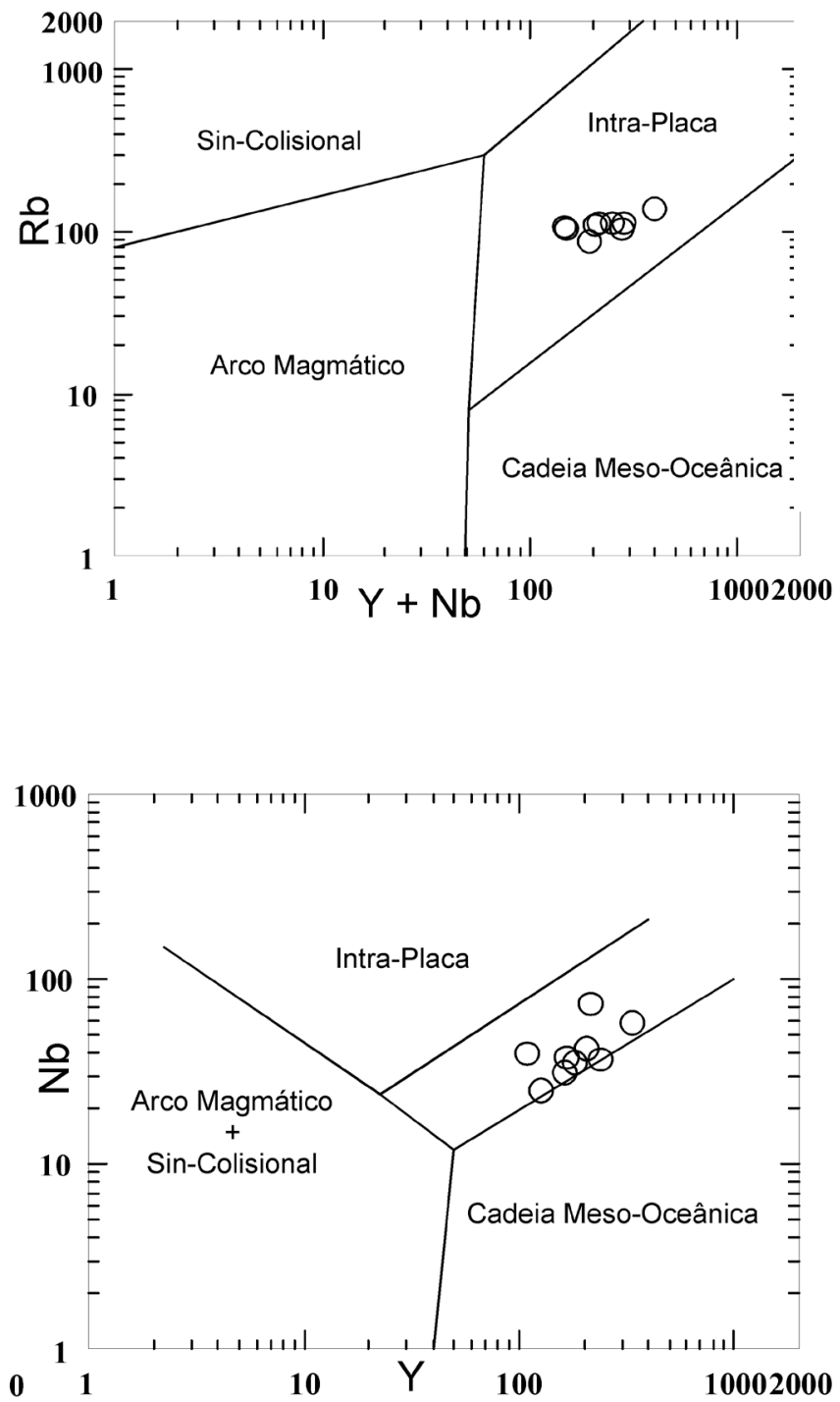

Figura 8 - Diagrama discriminante de ambiente tectônico para as rochas estudadas, segundo critérios propostos por Pearce et al. (1984). 


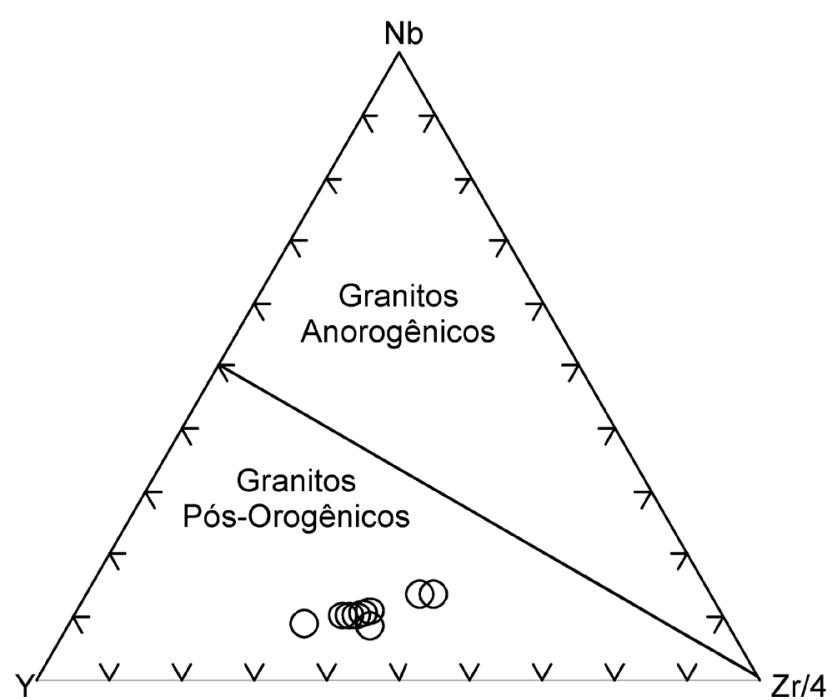

Figura 9 - Diagrama de classificação dos granitos estudados em relação aos parâmetros $\mathrm{Nb}-\mathrm{Y}-\mathrm{Zr} / 4$, (modificado de Eby 1992). Al = granitos tipo $A$ derivados de fontes semelhantes às de basalto de ilhas oceânicas; $A 2$ = granitos tipo $A$ derivados $d a$ crosta continental.

amostras de zircão foram analisadas isotopicamente pelo método $\mathrm{U}-\mathrm{Pb}$ e os resultados serão apresentados e discutidos abaixo.

Descrição das Amostras Morfologicamente, os cristais de zircão apresentam-se euédricos a subédricos, mostrando, na sua maioria, hábito prismático curto e tamanhos variados. As características morfológicas permitiram observar que a relação comprimento/largura é de $(2: 1)$ ou $(1: 1)$, sendo que a maioria desses cristais encontra-se metamitizados. As cores variam de incolor, amarelo e marrom, sendo comum ocorrer zoneamento interno nos cristais, evidência típica de cristalização magmática.

RESULTADOS E DISCUSSÕES Os dados analíticos obtidos para os zircões são mostrados na tabela 3 , totalizando 28 análises. As razões ${ }^{207} \mathrm{~Pb} /{ }^{206} \mathrm{~Pb}$ apontam para dois conjuntos de idades. Utilizando as frações de zircão analisadas e corrigidas para chumbo comum, foi montado um diagrama concórdia (Fig. 10) que mostra resultado concordante em $815 \pm 35 \mathrm{Ma}$, para o primeiro conjunto de idade, que corresponde, provavelmente, a herança isotópica da encaixante, conforme indicado pela presença de sobrecrescimento nos cristais e, também por este dado ter sido obtido no centro dos cristais analisados. Um segundo conjunto de dados em torno de $667 \pm 35$ Ma foi obtido nas bordas dos cristais, conforme diagrama concórdia, apresentado na figura 11, que pode ser interpretado como idade de cristalização desses granitóides.

Na região estudada são poucos os dados geocronológicos, excetuando-se algumas datações para a Faixa Paraguai e no Arco Magmático de Goiás (Tab. 4). Geraldes et al. (2003), apresenta idades ${ }^{40} \mathrm{Ar} /{ }^{39} \mathrm{Ar}$ em torno de $540 \mathrm{Ma}$, em micas da zona de cizalhamento do Araés, na região de Nova Xavantina, que interpretam como representativas do pico do metamorfismo de um evento colisional relacionado á colagem do oeste do Gondwana no continente Sul Americano. Esse evento

Tabela 3 - Dados Analíticos obtidos para zircão datados com razões ${ }^{207} \mathrm{~Pb}{ }^{206} \mathrm{~Pb}$ dos ortognaisses Itacaiu.

\begin{tabular}{|c|c|c|c|c|c|c|c|c|c|c|c|c|c|c|c|c|c|c|c|}
\hline Amostras & $\begin{array}{c}\text { Ratio } \\
7 / 6^{*}\end{array}$ & $1 \mathrm{~s}(\%)$ & $2 \mathrm{~s}(\%)$ & $\begin{array}{c}\text { Ratio } \\
6 / 8^{*}\end{array}$ & $1 \mathrm{~s}(\%)$ & $2 \mathrm{~s}(\%)$ & $\begin{array}{c}\text { Ratio } \\
7 / 5^{*}\end{array}$ & $1 \mathrm{~s}(\%)$ & $2 \mathrm{~s}(\%)$ & $\begin{array}{c}\text { Age } \\
7 / 6\end{array}$ & $\begin{array}{c}1 \mathrm{~s} \\
(\mathrm{Ma})\end{array}$ & $\begin{array}{c}2 \mathrm{~s} \\
(\mathrm{Ma})\end{array}$ & $\begin{array}{c}\text { Age } \\
6 / 8\end{array}$ & $\begin{array}{c}1 \mathrm{~s} \\
(\mathrm{Ma})\end{array}$ & $\begin{array}{c}2 \mathrm{~s} \\
(\mathrm{Ma})\end{array}$ & $\begin{array}{c}\text { Age } \\
7 / 5\end{array}$ & $\begin{array}{c}1 \mathrm{~s} \\
(\mathrm{Ma})\end{array}$ & $\begin{array}{c}2 \mathrm{~s} \\
(\mathrm{Ma})\end{array}$ & Rho \\
\hline $003 \mathrm{Z1} \quad 1-14$ & 0,061 & 1,8 & 3,5 & 0,111 & 2,5 & 5,1 & 0,929 & 3,1 & 6,2 & 627,4 & 37,8 & 75,6 & 679,0 & 16,4 & 32,7 & 667,1 & 15,1 & 30,2 & 0,8 \\
\hline $04 \mathrm{Z} 2 \quad 1-23$ & 0,067 & 1,7 & & 0,128 & 3,9 & & 1,191 & & & 844,8 & 35,4 & 70,7 & 779,3 & 28,7 & 57,5 & 796,4 & 23,6 & 47,1 & 0,9 \\
\hline 08 brb & 0,079 & 2,1 & 4,2 & 0,119 & 3,4 & 6,8 & 1,291 & 4,0 & 8,0 & 1162,3 & 41,6 & 83,2 & 725,7 & 23,3 & 46,6 & 841,9 & 22,9 & 45,7 & 0,9 \\
\hline $08 \mathrm{Z4}$ & 0,067 & 1,3 & 2,6 & 0,131 & 3,1 & & 1,209 & 3,4 & & 827,1 & 27,3 & 54,5 & 796,4 & 23,2 & 46,4 & 804,6 & 18,7 & 37,4 & 0,9 \\
\hline 11 Z5 1-19 & 0,060 & 4,5 & 8,9 & 0,113 & 5,6 & 11,1 & 0,938 & 7,1 & 14,3 & 614,1 & 96,5 & 192,9 & 689,0 & 36,3 & 72,6 & 671,7 & 35,0 & 70,0 & 0,8 \\
\hline $12 \mathrm{Z} 6$ & 0,071 & 1,8 & 3,6 & 0,125 & 3,6 & $7 ?$ & 1,219 & 4,0 & & 945,7 & 37,2 & 74,5 & 760,5 & 25,7 & 51,4 & 809,2 & 22,4 & 44,8 & 0,9 \\
\hline $15 \mathrm{Z7}$ & 0,095 & 2,9 & & & & & & & & 1518,2 & 53,8 & 107,7 & 739,3 & 23,7 & 47,3 & 963,7 & 27,6 & 55,1 & 0,8 \\
\hline $16 \mathrm{Z8}$ & 0,068 & 1,5 & 3,1 & 0,123 & 3,3 & 6,6 & 1,157 & 3,6 & 7,3 & 866,6 & 31,8 & 63,6 & 750,6 & 23,3 & 46,6 & 780,4 & 19,8 & 39,5 & 0,9 \\
\hline 19 Z9 & 0,065 & & & 0,131 & & & & & & 777,9 & 44,7 & 89,3 & 796,0 & 22,6 & 45,2 & 791,3 & 20,3 & 40,6 & 0,8 \\
\hline $20 \mathrm{Z10}$ & 0,068 & 1,5 & 3,0 & & 2,7 & & 1,235 & 3,1 & & 881,5 & 30,9 & 61,7 & 793,0 & 20,5 & 41,0 & 816,6 & 17,5 & 35,1 & 0,9 \\
\hline $23 \mathrm{Z11}$ & 0,079 & 1,5 & 3,0 & 0,132 & 3,3 & & 1,431 & 3,6 & & 1162,2 & 29,3 & 58,7 & 799,7 & 24,9 & 49,8 & 902,1 & 21,7 & 43,4 & 0,9 \\
\hline $24 \mathrm{Z12}$ & 0,072 & 2,0 & 4,0 & 0,117 & 3,7 & 7,4 & 1,163 & 4,2 & & 981,1 & 41,0 & 82,0 & 715,5 & 25,2 & 50,4 & 783,2 & 23,1 & 46,2 & 0,9 \\
\hline 27 Z13 & 0,069 & 1,3 & 2,6 & 0,131 & 3,6 & 7,2 & 1,241 & 3,8 & 7,6 & 893,6 & 26,9 & 53,7 & 792,6 & 26,8 & 53,5 & 819,6 & 21,5 & 42,9 & 0,9 \\
\hline $28 \mathrm{Z14}$ & 0,063 & 1,2 & 2,3 & 0,110 & 2,6 & 5,3 & 0,959 & 2,9 & 5,8 & 712,4 & 24,8 & 49,7 & 673,6 & 16,8 & 33,7 & 682,6 & 14,3 & 28,6 & 0,9 \\
\hline 31 Z15 & 0,102 & 3,1 & 6,3 & 0,126 & 3,7 & 7,4 & 1,781 & 4,9 & 9,7 & 1663,9 & 58,1 & 116,2 & 767,5 & 26,9 & 53,9 & 1038,6 & 31,7 & 63,3 & 0,8 \\
\hline $32 \mathrm{Z16}$ & 0,069 & 2,0 & 4,1 & 0,109 & 3,7 & 7,3 & 1,038 & 4,2 & 8,4 & 899,8 & 42,0 & 84,1 & 667,5 & 23,2 & 46,5 & 723,1 & 21,7 & 43,4 & 0,9 \\
\hline
\end{tabular}




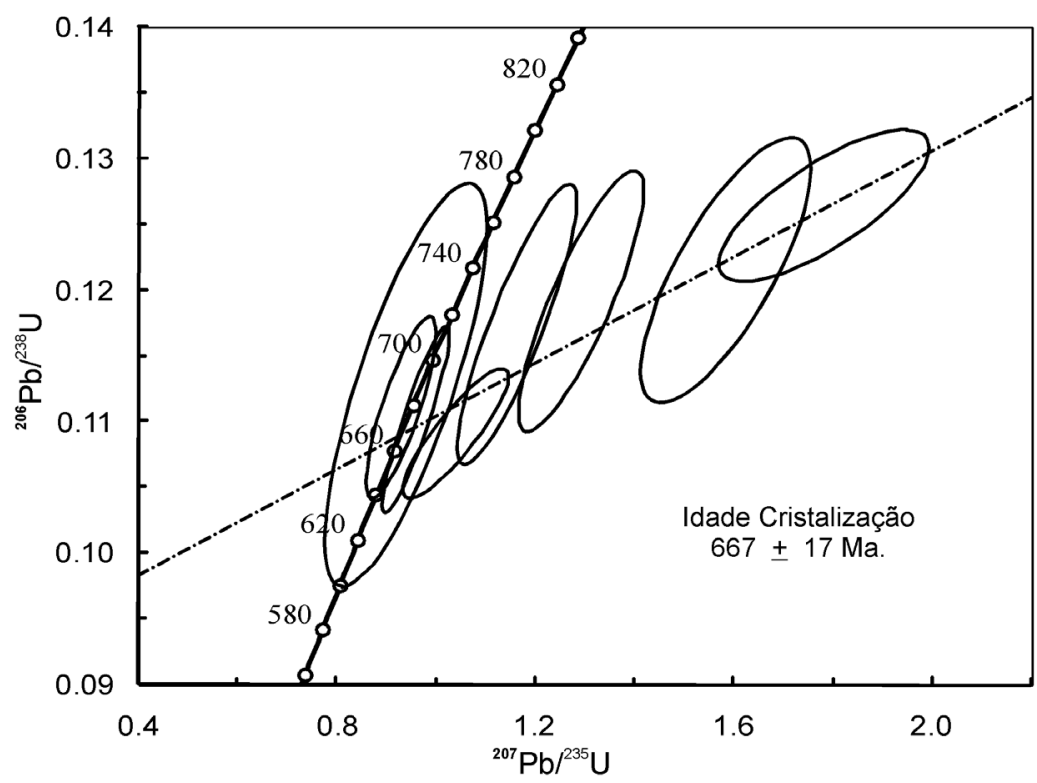

Figura 10 - Diagrama Discórdia e Concórdia U-Pb mostrando idade de cristalização dos ortognaisses em aproximadamente $667 \pm 8 \mathrm{Ma}$.

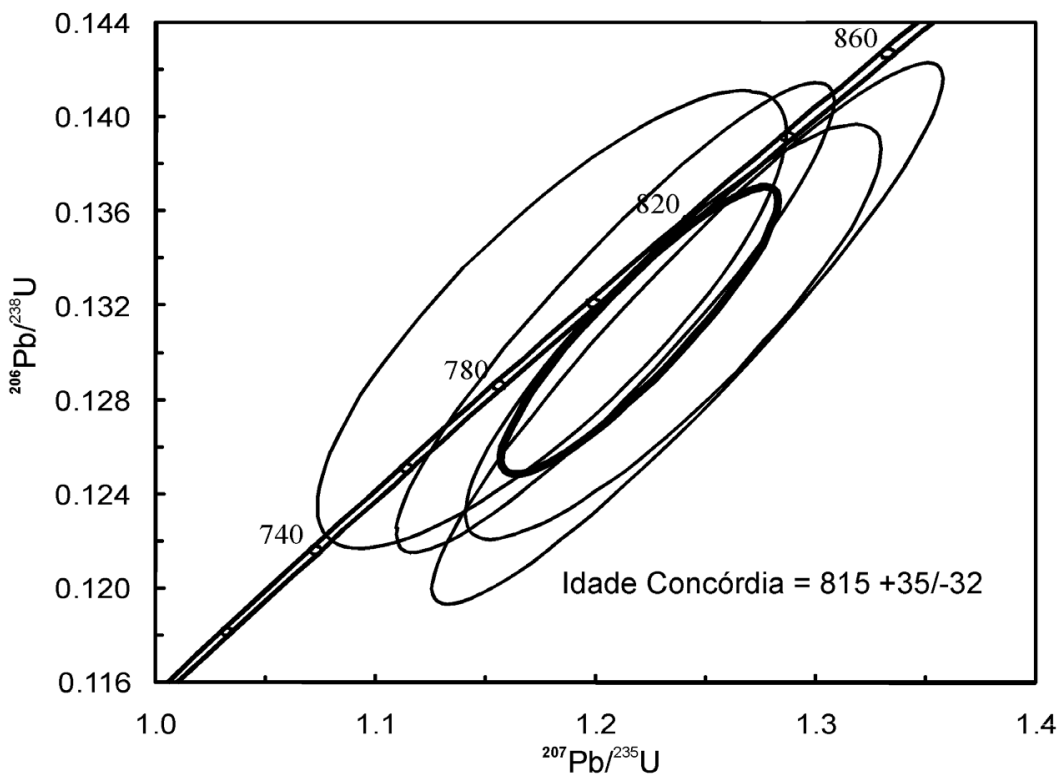

Figura 11 - Diagrama concórdia U-Pb mostrando idade de $815 \pm 35 \mathrm{Ma}$, interpretada como herdada.

metamórfico datado por Geraldes et al. (2003) pode ter sido responsável pelo processo de gnaissificação nas rochas estudadas. A tabela 4 apresenta para efeito de comparação, dados geocronológicos da área que se encontram disponíveis na literatura.

Ao se comparar as evidências de campo e dados laboratoriais obtidos para os ortognaisses encontrados a sul de Cocalinho com as rochas graníticas descritas por Souza (1997) no Complexo Ponta do Morro, é possível observar que essas duas unidades apresentam composição química levemente diferente e, embora ambos os tipos possam ser classificados como provenientes de ambiente intraplaca e apresentem associação típica de granitóides alcalinos do tipo A, a geração das mesmas ocorreu em épocas distintas, fato este reforçado pela presença de deformação e metamorfismo nos ortognaisses Itacaiu o que não ocorre nas rochas ígneas do Complexo Ponta do Morro. 
Tabela 4 - Síntese da evolução tectônica do Arco Magmático de Goiás, (adaptado de Pimente et al., 2004 e Dantas et al., 2006) citado por Chianiri 2007.

\begin{tabular}{|c|c|}
\hline $890-800 \mathrm{Ma}$ & $\begin{array}{l}\text { Formação de sistemas de arcos de ilhas intracratônicos caracterizados por rochas vulcânicas cálcio-alcalinas } \\
\text { e corpos plutônicos tonalíticos e dioríticos, alguns dos quais com características geoquímicas semelhantes a } \\
\text { magmas adakíticos. }\end{array}$ \\
\hline Ca. $800 \mathrm{Ma}$ & $\begin{array}{l}\text { Intrusões das séries inferiores dos complexos acamadados de Niquelândia, Barro Alto e Cana Brava, } \\
\text { possivelmente em ambiente de rift localizado em ambiente de back arc. }\end{array}$ \\
\hline $770-760 \mathrm{Ma}$ & $\begin{array}{l}\text { Metamorfismo de alto grau registrado especialmente nos três grandes complexos acamadados e menos } \\
\text { fortemente no Arco de Arenópolis. Eventos preliminares interpretados como resultado da colisão entre a } \\
\text { porção norte do Arco de Goiás e a borda do Cráton do São Francisco }\end{array}$ \\
\hline $760-680 \mathrm{Ma}$ & $\begin{array}{l}\text { Período de relativa quiescência ígnea. A pequena intensidade da atividade ígnea cálcio-alcalina pode } \\
\text { representar inclinação rasa da zona de subducção e limitada fusão da cunha do manto sobre esta. }\end{array}$ \\
\hline $670-600 \mathrm{Ma}$ & $\begin{array}{l}\text { Período de intensa atividade ígnea e tectônica com alojamento de inúmeros corpos tonalíticos- } \\
\text { granodioríticos-granitos e abundantes corpos máficos-ultramáficos diferenciados, não somente no Arco } \\
\text { Magmático de Goiás, como também no Complexo Anápolis-Itauçu. Assim são caracterizados no Arco dois } \\
\text { períodos de geração de magmas tonalíticos e acresção crustal. }\end{array}$ \\
\hline $630-600 \mathrm{Ma}$ & Pico do metamorfismo Brasiliano registrado em todas as rochas da Faixa Brasília \\
\hline$>600 \mathrm{Ma}$ & Soerguimento regional e magmatismo tipicamente pós-orogênico de caráter bimodal. \\
\hline
\end{tabular}

CONCLUSÕES Os dados aqui apresentados permitem concluir que os ortognaisses que afloram nas imediações de Cocalinho são o resultado do metamorfismo de uma rocha granítica com assinatura magmática típica de magma granítico do tipo A. Os dados geocronológicos mostraram valores aproximados de $815 \mathrm{Ma}$ que podem ser interpretados como produto de uma herança isotópica e outro valor de cerca de $667 \mathrm{Ma}$, interpretado como a idade de cristalização da rocha. Estes dados merecem ser melhores investigados, inclusive procurando informações sobre qual evento causou as deformações observadas nas rochas, ou seja, qual o último evento metamórfico a que estas rochas foram submetidas.

Para responder as 3 perguntas aventadas na introdução, será necessária a realização de outros estudos, já em andamento, e que visam elucidar o posicionamento destas rochas graníticas em relação às outras rochas aflorantes na região o que permitirá concluir o posicionamento tectônico das mesmas.

Agradecimentos Este trabalho foi financiado pela CAPES. Os autores agradecem a Maria Zélia Aguiar pelas discussões durante a interpretação dos dados petrológicos.

\section{Referências}

Almeida F.F.M. de. 1974. Sistema Tectônico Marginal do Cráton do Guaporé. In: SBG, Cong. Bras. Geol, 28, Porto Alegre, Anais, 4:09-17.

Almeida F.F.M. de. 1984. Província Tocantins - setor sudoeste, In: Almeida F.F.M. \& Hasui Y. (eds.) O Pré-Cambriano do Brasil. São Paulo, Ed. Blücher, p. 265-281.

Alvarenga C.J.S. \& Trompette R. 1993. Evolução Tectônica Brasiliana da Faixa Paraguai: A estruturação da região de Cuiabá. Rev.Bras. Geoc., 23:18-30.

Anderson J.L. \& Bender B. 1989. Nature and origin of Proterozoic Atype,granitic magmatism in the southwestern United States of America. Lithos, 23:19-52

Barbarin B. 1999. A review of the relationships between granitoid types, their origins and their geodynamic environments. Lithos, 46:605-626.

Bonhomme M.G., Cordani U.G., Kawashita K., Macedo M.H.F., Thomaz-FILHO A. 1982. Radiochronological age correlation of sediments in Brazil. Precambrian Research, 18:103-118.
Bonin B. 2007. A-type granites and related rocks: Evolution of a concept, problems and prospects. Lithos, 97:1-29.

Bowden P., Batchelor R.A., Chappell B.W., Didier J., Lameyre J. 1984. Petrological geochemical and source criteria for the classification of granitic rocks : a discussion. Physics of the Earth and Planetary Interiors, 35:1-11.

Collins W.J., Beams S.D., White A.J.R., Chappell B.W. 1982. Nature and origin of a type granites with particular reference to Southeastern Australia. Contrib.Mineral. Petrol., 80:189-200.

de la Roche H., Leterrier J., Grande Claude P., Marchal M. 1980. A classification of volcanic and plutonic rocks using R1-R2 diagrams and major element analyses-its relationships and current nomenclature. Chemical Geology, 29:183 210.

Eby G. N.1992. Chemical Subdivision of the A-type Granitoids: Petrogenetic and Tectonic Implications. Geology, 20:641-644.

Figueiredo A.J.A. \& Olivatti O. 1974. Projeto Alto Guaporé. 
Relatório Final Integrado. Escala 1:500.000. Goiânia: CPRM, 11. Convênio DNPM/CPRM.

Fuck R.A., Pimentel M.M., D’el Rey Silva L.J.H. 1994. In: SBG, Compartimentação tectônica da porção oriental da Província Tocantins. In: Congresso Brasileiro de Geologia, 38, Balneário Camboriú, Atas, p. 215-216.

Geraldes P., Sirois M.G., Tanguay J.F. 2003. Specific contribution of estrogen receptors on mitogen-activated protein kinase pathways and vascular cell activation. Circ. Res., 93:399-405.

Giret A., Bonin B., Kger J.M. (1980) Amphibole compositional trends in oversaturated and undersaturated alkaline plutonic ring-complexes. Canadian Mineralogist, 18:481-495.

Gioia S.M.C. 1997. Preparação da Metodologia Sm-Nd para Datacão de Amostras Geológicas e sua Aplicação em Rochas das areas de Firminópolis, Fazenda Nova e Americana do Brazil. Dissertação de Mestrado, Instituto de Geociências, Universidade de Brasília, 100p.

Kuyumjian R.M. 1994. Geologia da seqüência Mara Rosa na região da Chapada, Goiás. In: SBG, Simp. Geol. do Centro-Oeste, 4, Brasília, Atas, p.142-144.

Lacerda Filho J.V., Souza J.O., Oliveira C.C., Ribeiro P.S.E., Boas P.F.V., Albuquerque M.C., Frasca A.A.S., Borges F.R., Moreton L.C., Martins E.G., Camargo M.A., Valente C.R., Pimentel M.M., Botelho N.F. 2001. Geologia e Evolução Tectônica da Região Norte do Mato Grosso (Projeto Promin-Alta Floresta) In: SBG/Núcleo Norte, Simp. Geol. da Amazônia, 7, Belém, Resumos Expandidos, CD-Rom.

Loiselle M.C. \& Wones D.R. 1979. Characteristics and origin of anorogenic granites. In: Annual Meetings of the Geological Society of America and Associated Societies, San Diego, California, 11:468.

Maniar P.D. \& Piccolli P.M. 1989. Tectonic discrimination of granitoids. Geol. Soc. America Bull., 101:635-643.

Martinelli C.D. \& Batista J.J. 2003. Estratigrafia da seqüência metavulcanossedimentar dos Araés: Grupo Cuiabá? In: Simpósio de Geologia do Centro-Oeste, 8, Cuiabá, Atas, p.124-125.

Nakamura N. 1977. Determination of REE, Ba, Fe, Mg, Na and $\mathrm{K}$ in carbonaceous and ordinary chondrites. Geochemica at Cosmochimica Acta. 38:757-775.

Patiño-Douce A.E. 1997. Generation of metaluminous Atype granites by low-pressure melting of calc-alkaline granitoids. Geology, 25:743-746.

Pearce J., Harris N.B.W., Tindle A.D. 1984. Trace element discrimination diagrams for the tectonic interpretation of granitic rocks. J. Petrol., 25:956-983.

Pimentel M.M. \& Fuck R.A. 1992. Neoproterozoic crustal accretion in Central Brazil. Geology, 20:375-379.

Pimentel M.M., Fuck R.A, Machado N., Ribeiro R.K., Viana
M.G. 1993. Dados geocronológicos U-Pb preliminares da região de Mara Rosa, Goiás: implicações para a época de mineralização de Au e para a evolução tectônica neoproterozóica no Centro - Oeste. In: SBG, Cong. Brás. Geoq., 4, Brasília, Resumos Expandidos, p.255-258.

Pimentel M.M. \& Fuck R.A. 1987. Origem e evolução das rochas metavulcânicas e metaplutônicas da região de Arenópolis (GO). Rev. Bras. Geoc., 17:2-14.

Pinho F.E.C., Barbosa E.S., Pulz G.M., Ronchi L.H. 2003. Inclusões fluidas nos veios auríferos do depósito Pau-aPique, sudoeste do Cráton Amazonico. In: Ronchi L.H. \& Althoff F.J. (org.) Caracterização e modelamento dedepósitos minerais. São Leopoldo,UNISINOS v. 1, p. 293-311.

Pinho F. E. C. 1990. Estudo das rochas encaixantes e veios mineralizados a ouro do Grupo Cuiabá, na região denominada Garimpo do Araés, Nova Xavantina, Estado de Mato Grosso. Dissertação de mestrado, Instituto de Geociências, Universidade Federal do Rio Grande do Sul, Porto Alegre, $114 \mathrm{p}$.

Qiu J-S., Wang De-Zi, McInnes B.I.A., Jiang S-Y., Wang R.-C., Kanisawa S. 2005. Two subgroups of A-type granites in the coastal area of Zhejiang and Fujian Provinces, SE China: age and geochemical constraints on their petrogenesis. Transactions: Earth Sciences, 1-2:227-236.

Ribeiro Filho W. 1981. Reavaliação da geologia de PilarMara Rosa. In: SBG, Simp. Geol. do Centro-Oeste, 1, Goiânia, Atas, p.281-299.

Rodrigues J.B. 1996. Geocronologia e geoquimica da sequencia vulcano-sedimentar de Ipord e rochas graniticas associadas. Dissertação de Mestrado, Instituto de Geociências, Universidade de Brasília, 101p.

Schobbenhaus Filho C., Campos D.A., Derze G.R., Asmus H.E. 1984. Geologia do Brasil. Texto Explicativodo Mapa Geológico e da Área Adjacente Incluindo Depósitos Minerais. Brasília, DNPM, 501p.

Souza M.Z.A. 1997. Petrologia e geoquímica do complexo alcalino Ponta do Morro-MT. Tese de Doutoramento, Instituto de Geociências, Universidade de São Paulo, $168 \mathrm{p}$.

Viana M.G., Pimentel M.M., Whitehouse M.J., Fuck R.A., Machado N. 1995. O Arco Magmático de Mara Rosa, Goiás: dados geoquímicos e geocronológicos e suas implicações regionais. Rev.Bras. Geoc., 25:111-123.

Whalen J.W., Currie K.L., Chappell BW. 1987. A-type granites: geochemical characteristics, discrimination and petrogenesis. Contríb. Min. Petrol., 95:407-419.

Manuscrito ID 11146

Submetido em 19 de abril de 2008 Aceito em 24 de abril de 2009 